\title{
Working memory and intelligence quotient: Which best predicts on school achievement?
}

\author{
Gustavo Marcelino Siquara ${ }^{1}$ \\ Cassio dos Santos Lima ${ }^{2}$ \\ Neander Abreu ${ }^{2}$ \\ ${ }^{1}$ Escola Bahiana de Medicina e Saúde Pública, BA, Brasil \\ ${ }^{2}$ Universidade Federal da Bahia, BA, Brasil
}

\begin{abstract}
Working memory (WM) refers to ability to store and manipulate information for a period of time. There is evidence of a close relationship between WM and learning. The aim of this study was to investigate the relationship between WM, intelligence quotient (IQ) on school achievement. Individual neuropsychological assessment was conducted following a specific protocol. The study included 227 children aged 7 to 12 years $(\mathrm{M}=9.87, \mathrm{SD}=1.34)$, of which 119 were females, from private and public schools in Salvador, Bahia, Brazil. The data analysis included descriptive and inferential statistics. Academic achievement was evaluated using the Academic Performance Test (TDE), with subtests in reading, writing and arithmetic. The components of WM were evaluated using backward and forward Digit Span tasks and the backward and forward Corsi block-tapping task. The estimated IQ was assessed using tasks vocabularies and block design of the Wechsler scales. The statistical tests used were linear regression analysis (stepwise) and Pearson correlation. The results showed that the best predictors of academic performance were Digit Span Forward, Corsi Block Backward and Digit Span Backward task. The hypothesis of non-multicollinearity was tested, and it was verified that the constructs were independent (VIF $<10$ and Tolerance $>0.20$ ). The variance in academic performance explained by WM model was $\Delta \mathrm{R}=0.36$. High and significant correlations were observed between the components of WM and the TDE. The WM score (Digit Span Backward + Corsi Block Backward) and the TDE were correlated ( $\mathrm{r}=0.54 * *)$. These results indicate that WM is a good predictor of academic achievement than IQ and are consistent with other findings showing WM as a predictor of learning or the potential for learning. This result has important implications for education, particularly with respect to intervention.
\end{abstract}

Keyword: Working memory; Academic achievement; Executive function; Gc; Intelligence quotient (IQ).

\section{Memória de trabalho e quociente de inteligência: o que melhor prevê o desempenho escolar? \\ Resumo}

Memória de trabalho (MT) refere-se a capacidade de armazenar e manipular informações por um período de tempo. Há evidências de uma estreita relação entre MT e aprendizado. O objetivo deste estudo foi investigar a relação entre MT, quociente de inteligência (QI) no desempenho acadêmico. A avaliação neuropsicológica individual foi realizada seguindo um protocolo específico. O estudo incluiu 227 crianças com idades entre 7 a 12 anos $(M=9.87, \mathrm{SD}=1.34)$, das quais 119 eram do sexo feminino, de escolas privadas e públicas em Salvador, Bahia, Brasil. A análise de dados incluiu estatística descritiva e inferencial. O desempenho acadêmico foi avaliado usando o Teste de Desempenho Escolar (TDE), com subtestes de leitura, escrita e aritmética. Os componentes da MT foram avaliados usando tarefas de Span de Digitos e direta e inversa e a tarefa de Blocos de Corsi versão direta e inversa. O IQ estimado foi avaliado usando as tarefas de vocabulário e cubos das escalas Wechsler. Os testes estatísticos utilizados foram análise de regressão linear (enter) e correlação de Pearson. Os resultados mostraram que os melhores preditores de desempenho escolar foram as tarefas Digitos span direto, invertido e Cubos de Corsi direto e inverso. A hipótese de não-multicolinearidade foi testada, e verificou-se que os construtos foram independentes ( $\mathrm{VIF}<10$ e tolerância $>0,20$ ). A variância no desempenho acadêmico explicado pelo modelo $\mathrm{WM}$ foi $\Delta \mathrm{R}=0,12$. Correlações significativas foram observadas entre os componentes da MT e do TDE. $\mathrm{O}$ escore da MT (Dígito span do inverso + Corsi Block inverso) e o TDE foram correlacionados $(\mathrm{r}=0,28 * *)$. Estes resultados indicam que a MT é um bom preditor de realização escolar do que o QI e são consistentes com outros achados mostrando MT como um preditor de aprendizagem ou o potencial de aprendizagem. Este resultado tem implicações importantes para a educação, particularmente no que diz respeito à intervenção.

Palavras-chave: Memória de trabalho; Desempenho escolar; Função executiva; Gc; Quociente de inteligência (QI).

\section{Memoria de trabajo y cociente de inteligencia: ¿cuál predice mejor el logro escolar?}

\section{Resumen}

La memoria de trabajo (WM) se refiere a la capacidad de almacenar y manipular información durante un período de tiempo, y existe evidencia de una relación cercana entre la memoria de trabajo y el aprendizaje. El objetivo de este estudio fue investigar la relación entre la memoria de trabajo, la inteligencia (IQ) y el rendimiento escolar. La evaluación individual se realizó siguiendo un protocolo específico. El logro escolar se evaluó mediante la prueba de Logro escolar (TDE), con subpruebas en lectura, escritura y aritmética. Los componentes de la memoria de trabajo se evaluaron utilizando versiones anteriores y posteriores de Digit Span y las pruebas de bloqueo de tapado de Corsi. El IQ estimado se evaluó mediante las subpruebas Vocabulary and Block Design de 
Wechsler Intelligence Scale for Children III. El estudio incluyó a 227 niños de 7 a 12 años $(\mathrm{M}=9.87, \mathrm{SD}=1.34)$, de los cuales 119 eran mujeres, de escuelas privadas y públicas en Salvador, Bahía, Brasil. El análisis de los datos incluyó estadística descriptiva e inferencial. Las pruebas estadísticas utilizadas fueron el análisis de regresión lineal (enter) y la correlación de Pearson. Los resultados mostraron que los mejores predictores de Logros Escolares fueron el Digit Span hacia adelante, hacia atrás y Corsi bloquean las tareas hacia adelante y hacia atrás. Se probó la hipótesis de no multicolinealidad y se verificó que las construcciones eran independientes $(\mathrm{VIF}<10$ y Tolerancia $>0.20$ ). La variación en el rendimiento académico explicada por el modelo de memoria de trabajo fue $\Delta \mathrm{R}=0.12$. Se observaron correlaciones significativas entre los componentes de la memoria de trabajo y el TDE. La puntuación de la memoria de trabajo (Digit Span Backward + Corsi Block Backward) y el TDE se correlacionaron $(\mathrm{r}=0.28 * *)$. Estos resultados indican que la memoria de trabajo es un buen predictor del rendimiento escolar que el coeficiente intelectual y es consistente con otros hallazgos que muestran que la memoria de trabajo es un predictor del aprendizaje o el potencial de aprendizaje. Este resultado tiene implicaciones importantes para la educación, particularmente con respecto a la intervención.

Palabras clave: Memoria de trabajo; Rendimiento escolar; Función ejecutiva; Gc; Cociente de inteligencia (IQ).

\section{Introduction}

Nearly every aspect of human life depends on memory. Individuals who cannot encode, store, or retrieve information must rely on others for their survival. Because learning depends on memory, deficiencies in any aspect of memory can prevent children and adolescents from acquiring the skills and knowledge necessary for success in life (Dehn, 2008).

In the study of human cognitive function over the past thirty-five years, working memory (WM) has been one of the most influential constructs (Cowan, 2005). WM refers to the retention of information over a brief period of time, a function that is of central importance for a wide range of cognitive tasks and for academic achievement (Cowan, 2005). The capacity of WM is limited, and the imposition of excess storage or processing demands in the course of an ongoing cognitive activity will lead to catastrophic loss of information from this temporary memory system (Gathercole, Lamont, \& Alloway, 2006). Children who have difficulty manipulating mental information will most likely have difficulty learning new subjects.

Over the past twenty years, numerous studies have tested the hypothesis that WM is a process that forms the basis of the ability to learn (Zheng, Swanson, \& Marcoulides, 2011; Alloway, \& Passolunghi, 2011; Alloway \& Alloway, 2010; Rohde \& Thompson, 2007; Gathercole, Pickering, Knight, \& Stegman, 2004). WM is required whenever something is learned because learning requires the manipulation of information, interaction with long-term memory and the simultaneous storing and processing of information (Dehn, 2008). Poor WM has measurable impacts on children's academic performance (Holmes \& Gathercole, 2013). It is a common feature associated with educational underachievement (Gathercole et al., 2004), and a substantial majority of children with poor WM skills fails to meet expected standards in either reading or math, or, most commonly, both areas (Gathercole \& Alloway, 2008). Poor WM therefore appears to place a child at high risk of poor scholastic attainment (Holmes \& Gathercole, 2013).

Some studies have tested that WM ability, in comparison to fluid intelligence (Gf), contributes to better performance in reading and mathematics (Alloway \& Passolunghi, 2011; Alloway \& Alloway, 2010; Alloway, 2009; Rohde \& Thompson, 2007). Alloway \& Alloway (2010) showed that children's WM skills at 5 years of age were the best predictor of reading, spelling, and math outcomes six years later. Gf, in contrast, accounted for a smaller portion of the unique variance in reading and math skills and was not a significant predictor of spelling performance. These results demonstrate that WM is not same construct that Gf but rather represents a distinct cognitive skill with unique links to learning outcomes (Alloway \& Alloway 2010). Few studies have investigated the relationship of IQ with academic achievement. This suggests that WM deficiencies are associated with poor learning outcomes and are a high risk factor for school failure in children (Alloway, Gathercole, \& Elliott, 2010).

The majority of the studies comparing the predictive power of WM for academic performance are used to use the concept of Gf (Alloway \& Passolunghi, 2011; Alloway \& Alloway, 2010; Alloway, 2009), compared with studies that examine the predictive power for academic achievement from IQ.

WM capacity is usually measured by utilizing complex memory span tasks in which children must simultaneously store and process information (Gathercole \& Alloway, 2004). Gathercole, Pickering, Knight \& Stegmann (2004) found that WM skills were excellent predictors of whether children would obtain low, average or high scores on both English and math assessments at Key Stage 1 (6-7 years) and math assessments at Key Stage 3 (13-14 years). The study showed that WM, more than intelligence, is an 
excellent predictor of children's school achievement across domains (Lu, Weber, Spinath, \& Shi, 2011). This is also consistent with previous studies reporting that the specific associations between WM and achievement remain when controlling for intelligence (Alloway, 2009; Swanson, Jerman, \& Zheng, 2008; Maehler \& Schuchardt, 2009). Concerning the relationship between WM and intelligence, the moderate inter-correlation of .36 is in line with the view that the two constructs are not isomorphic (Lu, Weber, Spinath, \& Shi, 2011).

Academic achievement and development of verbal skills, such as reading decoding, reading comprehension, mathematics, and written expression, depend heavily on the adequate functioning of WM (Dehn, 2008). The strong relations between specific areas of academic achievement and short-term and WM components are well established (Berninger \& Richards, 2002; Swanson, 2001). Common classroom activities that impose simultaneous demands on storage and processing include listening to a speaker while trying to take notes, following complex instructions, decoding unfamiliar words, spelling sentences from memory and mental arithmetic. Learning is reduced, or at least slowed, when available WM capacity is reduced through overloading or dividing attention (Dehn, 2008).
Evaluation of WM development in the early school years and intervention programs for children with learning difficulties may reduce academic impacts. The research should investigate the cognitive functions that are key to academic performance to understand better the variables that influence the acquisition of new knowledge.

The aim of this study was to investigate the relationship between WM, IQ and academic achievement. In this study, we investigated whether WM or IQ is the best predictor of student academic performance as well as the relationship between WM with IQ. The hypothesis tested in the study is that more highly developed WM is associated with better academic achievement.

\section{Methods}

\section{Participants}

The study included 227 children between 7 and 12 years old $($ mean $=9.87, \mathrm{SD}=1.34)$, with 119 females and 108 males. All children were private or public school students between the 2nd and 5 th grades in Salvador, Bahia, Brazil.

TABLE 1

Socioeconomic characteristics of the study participants

\begin{tabular}{|c|c|c|c|c|c|}
\hline & $\begin{array}{c}\text { Attended Preschool } \\
(\%)\end{array}$ & $\begin{array}{c}\text { Educational Level } \\
\text { of Mother } \\
(\%)\end{array}$ & $\begin{array}{c}\text { Educational Level } \\
\text { of Father } \\
(\%)\end{array}$ & $\begin{array}{c}\text { Monthly Income } \\
(\%)\end{array}$ & $\begin{array}{c}\text { Reading Habits } \\
\text { of Children } \\
(\%)\end{array}$ \\
\hline No & 5.1 & & & & \\
\hline 1 to 2 years & 14.7 & & & & \\
\hline 3 to 4 years & 80.3 & & & & \\
\hline Incomplete Elementary School & & 3.6 & & & \\
\hline Elementary School I & & 1.8 & 2.9 & & \\
\hline Elementary School II & & 10.9 & 4.8 & & \\
\hline School & & 22.2 & 8.7 & & \\
\hline Graduation & & 24.9 & 31.4 & & \\
\hline Specialization / Masters & & 35.3 & 25.1 & & \\
\hline Doctorate & & 1.4 & 1.4 & & \\
\hline $\mathrm{R} \$ 151-300$ & & & & 1.5 & \\
\hline $\mathrm{R} \$ 301-600$ & & & & 5.3 & \\
\hline $\mathrm{R} \$ 600-1.200$ & & & & 17.7 & \\
\hline $\mathrm{R} \$ 1.200-2.400$ & & & & 7.2 & \\
\hline $\mathrm{R} \$ 2.400-4.800$ & & & & 7.2 & \\
\hline $\mathrm{R} \$ 4.800-6.000$ & & & & 6.7 & \\
\hline $\mathrm{R} \$ 6.000-10.000$ & & & & 23.0 & \\
\hline R $\$$ Above 10.000 & & & & 31.6 & \\
\hline Always & & & & & 22.5 \\
\hline Sometimes & & & & & 24.8 \\
\hline Frequently & & & & & 47.2 \\
\hline Never & & & & & 5.5 \\
\hline
\end{tabular}


Table 1 displays the socioeconomic profile of participants. Most studied in preschool for at least 3 years $(80.3 \%)$. Parents generally had a middle level of education. The monthly income of the participants was also good distribution.

\section{Procedures}

The parents consented to the participation of their children in the study, i.e., they signed a consent form and received a copy of the document. Children who had been authorized underwent neuropsychological assessment. Individual neuropsychological assessment was conducted following a specific protocol. All testing occurred during school hours and was conducted in the classes of the participants, with an estimated duration of 1 hour and a half. The parents were sent a socioeconomic questionnaire. This questionnaire aimed to assess whether the child took medication or had any medical problems, such as prematurity, low birth weight or psychiatric or neurological illness. To participate in the study, children could not present any health problems.

\section{Data Analysis}

The data analysis used descriptive and inferential statistics. The descriptive statistics included the mean, standard deviation, and range. The inferential statistics included bivariate correlations and linear regression analysis. The software used was SPSS version 20 (IBM, 2011).

\section{Instruments}

Intelligence (IQ Estimated). The IQ of the children was estimated using the vocabulary and cube tasks of the Wechsler Intelligence Scale for Children, $3^{\text {rd }}$ Version (WISC-III) (Wechsler, 2002). Mello et al. (2011) reported on the feasibility of estimating a child's IQ through these two tasks.

Vocabulary (WISC-III). The child is asked to provide settings for a list of 35 words that are read one by one.

Block Design (WISC-III). The child is given 16 white and red blocks and is shown figures made up of white and red cubes. The child is asked to assemble the blocks to correspond to the figure, a task requiring mental decomposition and rotation of the figure.

Short Term Memory (STM) and Working Memory $(W M)$. To evaluate STM and WM, the digit span task from the WISC-III and the Corsi Block-tapping Test were used, both forward and backward versions of the tasks.

Digit Span (WISC-III). The examiner reads aloud a sequence of numbers. For the forward version of the task, the child repeats the numbers in the same order in which they were spoken (assessment of STM). For the backward version, the child repeats the numbers in reverse order (assessment of WM).

Corsi Block Test. The task includes nine cubes mounted on a board (Lezak, 1995). The examiner touches the blocks in a specific sequence and asks the child to repeat the sequence in the same order for the forward version of the task (assessment of STM). For the backward version, the examiner touches the blocks, forming a sequence, but the child must touch them in reverse order (assessment of WM).

\section{Academic achievement}

Academic achievement was assessed with a Brazilian instrument, the "Teste de Desempenho Escolar" (TDE). The TDE is a psychometric instrument with individual application to the evaluation of the fundamental capabilities of school performance, specifically spelling, arithmetic and reading (Stein, 1994). It is designed for evaluation of students from 1st to 6th grade of elementary school, although it can be used with some reservations for the 7 th and 8 th grades. It has been validated in Brazil using a sample from Porto Alegre. This test evaluates the fundamental skills of students using the following tasks: 1 . Spelling: Students listen to and write 34 single words presented in dictation form; 2. Arithmetic: Students are given 3 mathematical problems in oral form and 35 written arithmetic calculations, fora total of 38 ; 3 . Reading: Students are asked to recognize 70 isolated words in context. The total score for each task is obtained from the sum of each correct answer that the participant has obtained (Stein, 1994).

\section{Results}

Table 2 shows the performance of the children on the WM tasks and the TDE. The data in Table 2 present the skewness and kurtosis as indicators of the normal tendency of the tasks in the sample. In all tasks, the skewness was smaller than one and the kurtosis closer to zero.

Table 3 shows the children's performance for each task, comparing age groups. It can be observed that STM and WM improve with age, and the performances of the children on the TDE also improve with age. Despite this improvement in performance, it was not possible to separate the participants into homogenous groups using a post-hoc ANOVA. The mean estimated IQ was above average (110), indicating a medium intelligence level for the participants. 
TABLE 2

Descriptive statistics of row scores for measures cognitive

\begin{tabular}{lcccccc}
\hline & Min. & Max. & Skewness & Kurtosis & Mean & SD \\
Digit Span Forward & 3 & 15 & 1.063 & 1.856 & 7.51 & 2.04 \\
Digit Span Backward & 1 & 11 & .817 & 1.226 & 4.49 & 1.62 \\
Corsi Block Test Forward & 3 & 12 & -.188 & .553 & 7.68 & 1.53 \\
Corsi Block Test Backward & 1 & 12 & -.359 & -.359 & 7.04 & 2.18 \\
TDE Total & 3.00 & 138.00 & -1.835 & -3.699 & 105.34 & 27.9 \\
WM Total & 2 & 20 & -.026 & -.029 & 12.15 & 3.01 \\
\hline
\end{tabular}

WM Total (Digit Span Backward+Corsi Block Test Backward).

TDE Total (Arithmetic + Reading + Spelling).

TABLE 3

Performance for age in each of the cognitive tasks

\begin{tabular}{|c|c|c|c|c|c|c|c|}
\hline \multirow{2}{*}{\multicolumn{2}{|c|}{$\begin{array}{c}\text { Component } \\
\text { Sub-component }\end{array}$}} & \multicolumn{2}{|c|}{ Short-Term Memory } & \multicolumn{2}{|c|}{ Working Memory (WM) } & \multirow{3}{*}{ WM Total } & \multirow{3}{*}{ TDE Total } \\
\hline & & \multirow{2}{*}{$\begin{array}{l}\text { Verbal } \\
\text { Digit Span } \\
\text { Forward }\end{array}$} & \multirow{2}{*}{$\begin{array}{l}\text { Visuo-Spatial } \\
\text { Corsi Block Test } \\
\quad \text { Forward }\end{array}$} & \multirow{2}{*}{$\begin{array}{c}\text { Loop Phonological } \\
\text { Digit Span } \\
\text { Backward }\end{array}$} & \multirow{2}{*}{$\begin{array}{c}\text { Visuo-Spatial } \\
\text { Sketchpad } \\
\text { Corsi Block Test } \\
\text { Backward }\end{array}$} & & \\
\hline Age & $N$ & & & & & & \\
\hline 7 & 7 & $7.14(0.9)$ & $6.71(0.7)$ & $3.86(1.0)$ & $5.29(2.4)$ & $9.14(2.5)$ & $87.00(7.3)$ \\
\hline 8 & 18 & $7.06(0.9)$ & $7.22(1.6)$ & $4.22(1.7)$ & $5.22(1.7)$ & $9.44(2.7)$ & 101.94(8.6) \\
\hline 9 & 37 & $7.54(1.5)$ & $7.86(1.1)$ & $4.32(1.3)$ & $7.16(2.2)$ & $11.48(2.7)$ & $110.51(9.45)$ \\
\hline 10 & 45 & $8.02(1.6)$ & 7.64(1.1) & $4.69(1.4)$ & $7.76(1.6)$ & $12.44(2.4)$ & $118.40(8.87)$ \\
\hline 11 & 27 & $7.4(1.4)$ & $8.44(1.7)$ & $5.39(1.6)$ & $8,19(1.7)$ & $13.62(2.6)$ & $124.70(13.92)$ \\
\hline 12 & 14 & $9.57(2.0)$ & $9.00(2.0)$ & $5.57(1.4)$ & $9,43(1.2)$ & $15(1.9)$ & $132.00(5.39)$ \\
\hline Total & 148 & $7.79(1.6)$ & $7.88(1.4)$ & $4.72(1.5)$ & $7.42(2.1)$ & $12.14(3.0)$ & $115.46(14.29)$ \\
\hline
\end{tabular}

WM Total (Digit Span Backward+Corsi Block Test Backward).

TDE Total (Arithmetic + Reading + Spelling).

Table 4 shows the correlations between the tasks of the TDE and the measures of memory. All correlations between the reading, spelling and mathematics tasks and the memory measures were significant. The Arithmetic Task had the highest correlation with performance on the Corsi Block Backward ( $\mathrm{r}=.59$, $p \leq 0.01)$. The Reading Task showed the strongest correlation with the Digit Span Forward task $(\mathrm{r}=.43$, $p \leq 0.01)$. For the Spelling Task, the correlations were similar among the Corsi Block Backward, Digit Span Forward, and Digit Span Backward tasks $(r=.41, r=.48$ and $\mathrm{r}=.37$, respectively, all with $\mathrm{p} \leq 0.01)$.

TABLE 4

Bivariate correlational analysis between school performance, short-term memory and working memory

\begin{tabular}{|c|c|c|c|c|c|c|c|c|c|c|}
\hline & 1 & 2 & 3 & 4 & 5 & 6 & 7 & 8 & 9 & 10 \\
\hline 1. Corsi Block Forward & - & & & & & & & & & \\
\hline 2. Corsi Block Backward & $.451^{* *}$ & - & & & & & & & & \\
\hline 3. Digit Span Forward & $.268^{* *}$ & $.376^{* *}$ & - & & & & & & & \\
\hline 4. Digit Span Backward & $.269^{* *}$ & $.361^{* *}$ & $.443 * *$ & - & & & & & & \\
\hline 5. WM Total & $.451 * *$ & $.879 * *$ & $.488 * *$ & $.762 * *$ & - & & & & & \\
\hline 6. QI Estimated & $.235^{* *}$ & $.351 *$ & $.355^{* *}$ & $.291 * *$ & $.392 *$ & - & & & & \\
\hline 7. Arithmetic & $.377^{* *}$ & $.590 * *$ & $.450 * *$ & $.406 * *$ & $.617 * *$ & $.324 * *$ & - & & & \\
\hline 8. Reading & $.252 * *$ & $.332 * *$ & $.436^{* *}$ & $.376^{* *}$ & $.423 * *$ & $.424 * *$ & $.545 * *$ & - & & \\
\hline 9. Spelling & $.299 * *$ & $.413 * *$ & $.482 * *$ & $.371 * *$ & $.475 * *$ & $.435 * *$ & $.684 * *$ & $.817 * *$ & -- & \\
\hline 10. TDE Total & $.336^{* *}$ & $.473 * *$ & $.506^{* *}$ & $.428 * *$ & $.546^{* *}$ & $.448 * *$ & $.785 * *$ & $.929 * *$ & $.934 * *$ & - \\
\hline
\end{tabular}

$* p \leq 0.05 ; * * p \leq 0.01$.

WM Total (Digit Span Backward + Corsi Block Test Backward).

TDE Total (Arithmetic + Reading + Spelling). 
Of interest was the finding (Table 4) that academic achievement (TDE Total) showed the highest positive correlations with the WM tasks (Corsi Block Backward, $r=.47$, and Digit Span Backward, $r=.42$, $p \leq 0.01)$. Another strong positive correlation occurred between TDE Total and WM $(r=.56, p \leq 0.01)$ and the Arithmetic WM task $(\mathrm{r}=.54, p \leq 0.01)$. Interestingly, the task of Digit Span Forward showed higher positive correlations with the Spelling and Reading tasks $(\mathrm{r}=.48$ and $\mathrm{r}=.43 ; p \leq 0.01)$; however, when we analyzed overall academic achievement (TDE total), the Digit Span Backward task had a higher correlation $(\mathrm{r}=.42$; $p \leq 0.01$ ).

TABLE 5

Linear regression to predict academic achievement (TDE total) from WM task

\begin{tabular}{|c|c|c|c|c|c|}
\hline & $R^{2}$ & $\Delta R$ & $B$ & $\begin{array}{c}\text { Std. } \\
\text { Error } \\
B\end{array}$ & $\beta$ \\
\hline Step 1 & .25 & .25 & & & \\
\hline Constant & & & 52.344 & 6.20 & \\
\hline Digit Span Forward & & & 3.366 & .483 & $.508 * *$ \\
\hline Step 2 & .35 & .34 & & & \\
\hline Constant & & & 35.86 & 6.51 & \\
\hline Digit Span Forward & & & 5.29 & .489 & $.382 * *$ \\
\hline Corsi Block Backward & & & 4.19 & .662 & $.328 * *$ \\
\hline Step 3 & .37 & .36 & & & \\
\hline Constant & & & 31.81 & 6.52 & \\
\hline Digit Span Forward & & & 4.44 & .839 & $.761 * *$ \\
\hline Corsi Block Backward & & & 3.64 & .753 & $.806^{* *}$ \\
\hline Digit Span Backward & & & 3.17 & 1.034 & $.776 * *$ \\
\hline
\end{tabular}

$* p \leq 0.01 ; * * p \leq 0.001$.

TABLE 6

Linear regression to predict academic achievement (TDE total) from IQ estimated $(\mathrm{Gc})$

\begin{tabular}{lccccc}
\hline & $R^{2}$ & $\Delta R$ & $B$ & $\begin{array}{c}\text { Std. Error } \\
B\end{array}$ & $\beta$ \\
Step 1 & .19 & .19 & & & \\
Constant & & & 30.906 & 10.160 & \\
IQ Estimated & & & .671 & .0 .91 & $.444^{* *}$ \\
\hline
\end{tabular}

$* p \leq 0.01 ; * * p \leq 0.001$.

TABLE 7

Linear regression to predict performance in sub-test arithmetic from visuospatial working memory

\begin{tabular}{lccccc}
\hline & $R^{2}$ & $\Delta R$ & $B$ & $\begin{array}{c}\text { Std. Error } \\
B\end{array}$ & $\beta$ \\
Step 1 & .30 & .30 & & & \\
Constant & & & 6.54 & 1.98 & \\
Corsi Block Backward & & & 2.03 & .483 & $.554^{* *}$ \\
\hline
\end{tabular}

$* p \leq 0.01 ; * * p \leq 0.001$.
The correlations between the estimated IQ measure and academic achievement (TDE) were significantly. All correlations was a medium power include TDE total $(\mathrm{r}=.54, p \leq 0.01)$. For the other measures of TDE estimated IQ also showed good correlations.

Table 5 shows the results of the linear regression model using the STM tasks (Digit Span Forward and Corsi Block Forward) and the WM tasks (Corsi Block Backward and Digit Span Backward) to predict total TDE (Arithmetic + Reading + Spelling). A stepwise method was used to build the regression model. The results of the construction of the model indicate that the tasks that best explained the TDE variance were Digit Span Forward, Corsi Block Backward and Digit Span Backward. The greatest variance was explained specifically by the WM tasks. The Digit Span Forward, Corsi Block Backward and Digit Span Backward, explained together $(\Delta \mathrm{R}=.36)$ of the TDE total. The Corsi Block Forward task did not significantly explain any variance in the model, so it was then excluded in the stepwise method. The hypothesis of non-multicollinearity was tested, and it was verified that the constructs were independent (VIF $<10$ and Tolerance $>0,20)$. The requirements of linearity and homoscedasticity were met.

The IQ submitted an variance explained less than WM tasks, but showed a significant prediction $(\Delta \mathrm{R}=.19)$. The hypothesis of non-multicollinearity was tested, and it was verified that the constructs were independent ( $\mathrm{VIF}<10$ and Tolerance $>0,20)$.

Table 7 shows the results of the linear regression model using only Corsi Block Forward to predict Arithmetic TDE. The data showing above is interesting because only one task which assesses visuospatial WM is predicting a good value for the test of arithmetic TDE.

\section{Discussion}

The aim of the study was to analyze the correlational and predictive power of WM and estimated IQ with regard to academic achievement. The findings of the study indicate good correlations between WM and academic achievement, more specifically, reading, spelling and mathematics. Previous published studies also indicate these correlations between WM and academic achievement (Alloway, 2009; Alloway, 2006; Rasmussen \& Bisanz, 2005; Cowan \& Alloway, 2008). Overall correlations between WM measures and achievement range as high as .55 to .92 (Swanson, 1999). There is a strong empirical foundation for the view that learning difficulties reflect a fundamental deficit in WM (Swanson \& Siegel, 2001). 
The current study found results consistent with the literature, i.e., the tasks that had good correlations with academic achievement were WM tasks. WM requires executive resources for the processing aspect of the task. The link suggests that the ability to mentally store and manipulate information may allow a greater capacity for learning, explaining the higher correlations and prediction model between academic achievement and WM tasks. Interestingly, the analysis showed one of the largest correlations between the total score of the WM tasks and the total score on reading, spelling and mathematics. This may indicate that the ability to manipulate the information actually improves verbal and spatial learning ability. A higher correlation between verbal aspects from WM and tasks of reading and spelling was observed. This may be related to the development of components of WM (phonological loop and visuospatial sketch) with the greatest ability to manipulate verbal and spatial information.

Another task used which showed excellent relationships with performance in arithmetic was the task of Corsi Block Backward. Only this task showed a variance explained $(\Delta R=30)$. These findings may indicate that the ability of visuospatial manipulation can predict performance in mathematics in children. Studies such as Meyer, et al. (2010) argue that tasks involving the central executive of working memory facilitate the learning of mathematics.

The Corsi Block task showed a good prediction on arithmetic performance. It is likely that this result is explained by a greater capacity of visuospatial manipulation. With the further development of the visuospatial sketch the child can accomplish more manipulations and mental rotations from visual stimuli as presented on mathematical tasks. Some studies in the literature indicate the importance of the development of the visuospatial sketch for the mathematical tasks (Andersson\& Lyxell, 2006, Zheng, Swanson, \& Marcoulides, 2011). This finding may contribute to the identification of mathematical problems..

Another important finding was that WM improves with increasing age. This demonstrates that storage and manipulation of information also increases. Other studies also report similar findings (Gathercole, Alloway 2008; Alloway 2006), with implications especially in the classroom. However, this pattern was not observed in homogeneous groups using a post-hoc ANOVA according to age. Perhaps WM develops along a continuum with no specific landmarks in accordance with age. These findings point to the importance of the development of WM for academic achievement and learning. Many studies now indicate failures in the development of WM in children with learning difficulties (Alloway, 2006; Lu et al. 2011; Alloway, Gathercole, Elliott, 2010; Gathercole, 2008; Henry \& Winfiel, 2010; Meyer, Salimpoor, Wu, Geary, Menon, 2010).

The estimation of IQ was made through the WISCIII tasks. These tasks assess crystallized intelligence and are associated with specific aspects of learning. This intelligence was developed from cultural and educational experiences, present in most school activities (Cronbach, 1996). The findings of the study indicate that IQ $(\mathrm{Gc})$ has significant relationship to academic achievement. Many studies have assessed fluid intelligence, and correlations are lower when compared with WM (Unsworth \&Engle, 2005; Lu et al. 2011; Hornung, Brunner, Reuter, Martin, 2011). However Gc and predictions showed good relations with academic performance, although these relations are weaker than the WM.

In the regression model, TDE was explained mainly from the WM tasks. The amount of variance in performance on the TDE that was explained by the tasks used was $36 \%$. Interestingly the explanation of academic achievement was mainly due to the WM tasks. This indicates the strength of WM tasks in predicting overall performance on the TDE. Other studies, such as that by Alloway (2009), included regression models that also indicated strong relationships between WM and academic achievement. The findings from the regression analyses indicated that both WM capacity and prior domain-specific knowledge were unique predictors of learning outcomes 2 years later. The finding that initial reading and math skills are important precursors to subsequent learning fits well with the existing literature (Swanson, 2006; Butterworth, 2005). IQ was not a significant predictor of learning outcomes once WM capacity and prior knowledge were statistically controlled. It is also of interest that working-memory capacity predicted subsequent skills in both reading and math (Alloway, 2009). The evidence from the study indicates that WM is a good predictor of academic achievement, as measured by TDE tasks.

The findings of this study are consistent with others indicating that poor WM is associated with poor academic attainment. It fits in with the notion that WM is the foundation of learning (Martinussen, Hayden, Hogg-Johnson, Tannock, 2005) and is associated with learning disabilities regardless of the core deficit (Nigg, 2006). Early screening of WM problems can prevent subsequent learning difficulties (Alloway, Gathercole \& Elliott, 2010). While there are a range of cognitive skills that are crucial to learning, there is growing evidence that WM is one of the best predictors 
of attainment (Alloway, Banner \&Smith, 2010). The identification of this strong relationship between WM performance and academic studies is interesting and could lead to development of interventions to stimulate WM. Training programs that directly target WM provide important evidence that it is possible to make enduring changes to these memory abilities. Cogmed Working Memory Training provides intensive practice on a range of computer-based memory tasks over 20-25 sessions (Klingberg, Forssberg, \& Westerberg, 2002; Klingberg et al., 2005). There is also preliminary evidence of accelerated learning following such training, with significant improvements in math scores reported several months after training for children with WM impairments (Holmes, Gathercole, Dunning,
2009) and improvements in reading comprehension reported post-training for children with special educational needs (Dahlin, 2010).

In summary, the data from the research suggests that WM predicts academic achievement, specifically performance in reading, spelling and arithmetic. The ability of visuospatial manipulation seems to be closely linked to performance in mathematics. The results of the regression model indicate that the ability to manipulate information is intimately linked to learning. Compared to WM, estimated IQ (Gc) showed lower correlations and predictive power of academic achievement. Finally, this study indicates that the best the development of WM, the best the school performance in children.

\section{References}

Alloway, T. P. (2006). How does working memory work in the classroom? Educational Research and Reviews, 1(4), 134-139.

Alloway T. P. (2009) Working memory but not IQ predicts sub- sequent learning in children with learning difficulties. European Journal Psychology Assessment, 25, 92-98. https://doi.org/10.1027/1015-5759.25.2.92

Alloway, T. P. Banner, G. E. \& Smith, P. (2010). Working memory and cognitive styles in adolescents' attainment. British Journal of Educational Psychology, 80, 567-581. https://doi.org/10.1348/000709910X494566

Alloway, T. P. \& Passolunghi, M. C. (2011).The relationship between working memory, IQ, and mathematical skills in children. Learning and Individual Differences, 21(1), 133-137. https://doi.org/10.1016/j.lindif.2010.09.013

Alloway, T. P., Gathercole, S. E., \& Elliott, J. (2010).Examining the link between working memory behaviour and academic attainment in children with ADHD. Developmental medicine and child neurology, 52(7), 632-6. https://doi. org/10.1111/j.1469-8749.2009.03603.x

Alloway, T. \& Alloway, R. G. (2010).Investigating the predictive roles of working memory and IQ in academic attainment. Journal of Experimental Child Psychology, 106(1), 20-29. Elsevier Inc. https://doi.org/10.1016/j. jecp.2009.11.003

Atkinson, R. C. \& Shiffrin, R. M. (1968). Human memory: a proposed system and its control processes. In The Psychology of Learning and Motivation: Advances in Research and Theory (pp. 89-195). New York: Academic. https://doi. org/10.1016/S0079-7421(08)60422-3

Berninger, V. W. \& Richards, T. L. (2002). Brain literacy for educators and psychologists. New York: Academic Press.

Butterworth, B. (2005). The development of arithmetical abilities. Journal of Child Psychology and Psychiatry, 46, 3-18. https://doi.org/10.1111/j.1469-7610.2004.00374.x

Cronbach, L. J. (1996). Fundamentos da testagem psicológica. Porto Alegre: Artes Médicas.

Cowan, N. (2005). Working Memory Capacity.New York: Lawewnce Erlbaum.

Cowan, N. \& Alloway, T. P. (2008). The development of working memory. In N. Cowan (Ed.), Development of memory in childhood, Hove: Psychology Press.

Dahlin, K. (2010). Effects of working memory training on reading in children with special needs. Reading and Writing, 24, 479-491. https://doi.org/10.1007/s11145-010-9238-y

Dehn, M. J. (2008) Working memory and academic learning: assessment and intervention. Jonh Wiley \& Sons, Hoboken, New Jersey.

Gathercole, S. E. (2008). Working memory in the classroom. Psychologist, 21, 382-385.

Gathercole, S. E. \& Alloway, T. P. (2004). Working memory and classroom learning. Dyslexia Review, 15, 4-10.

Gathercole, S. E. \& Alloway, T. P. (2008). Working memory and learning: A guide for teachers. Sage: UK.

Gathercole, S. E., Lamont, E. \& Alloway, T. P. (2006) Working memory in the classroom. In S. J. Pickering (Ed.). Working memory and Education (pp. 219-240). Burlington, MA: Academic Press. https://doi.org/10.1016/B978012554465-8/50010-7

Gathercole, S. E., Pickering, S. J., Knight, C., \& Stegmann, Z. (2004).Working memory skills and educational attainment: Evidence from National Curriculum assessments at 7 and 14 years of age. Applied Cognitive Psychology, 40, 1-16. https://doi.org/10.1002/acp.934 
Gathercole, S. E., Pickering, S.J., Knight, C., \& Stegman, Z. (2004).Working memory skills and educational attainment: Evidence from National Curriculum assessments at 7 and 14 years of age. Applied Cognitive Psychology, 18, 1-16. https://doi.org/10.1002/acp.934

Henry, L. Winfiel, J. (2010). Working memory and educational achievement in children with intellectual disabilities. Journal of Intellectual Disability Research, 54, (4), 354-365. https://doi.org/10.1111/j.1365-2788.2010.01264.x

Holmes, J. \& Gathercole, S. E. (2013).Taking working memory training from the laboratory into schools, Educational Psychology. An International Journal of Experimental Educational Psychology. https://doi.org/10.1080/01443410. 2013.797338

Holmes, J., Gathercole, S., E., Dunning, D. L. (2009). Adaptive training leads to sustained enhancement of poor working memory in children. Development Science, 12, 9-15. https://doi.org/10.1111/j.1467-7687.2009.00848.x

Hornung, C., Brunner, M., Reuter, R. A. P., \& Martin, R. (2011).Children's working memory: Its structure and relationship to fluid intelligence. Intelligence, 39(4), 210-221. https://doi.org/10.1016/j.intell.2011.03.002

Jarrold, C. Towse, J. N. (2006). Individual Differences in Working Memory. Neuroscience, 139, 39-50. https://doi. org/10.1016/j.neuroscience.2005.07.002

Klingberg, T., Fernell, E., Olesen, P. J., Johnson, M., Gustafsson, P., Dahlstrom, K. Westerberg, H. (2005). Computerised training of working memory in children with ADHD-a randomised, controlled trial. Journal of the American Academy of Child and Adolescent Psychiatry, 44, 177-186. https://doi.org/10.1097/00004583-200502000-00010

Klingberg, T., Forssberg, H., \& Westerberg, H. (2002).Training of working memory in children with ADHD. Journal of Clinical and Experimental Neuropsychology, 24, 781-791. https://doi.org/10.1076/jcen.24.6.781.8395

Lezak, M. D. (1995) Neuropsychological Assessment, Oxford University Press.

Lu, L. Weberc, H. S. Spinath, F. M., Shi, J. (2011) Predicting school achievement from cognitive and non-cognitive variables in a Chinese sample of elementary school children. Intelligence, 39, 130-140. https://doi.org/10.1016/j. intell.2011.02.002

Maehler, C. \& Schuchardt, K. (2009). Working memory functioning in children with learning disabilities: does intelligence make a difference? Journal of Intellectual Disability Research, 53(1), 3-10. https://doi.org/10.1111/j.13652788.2008.01105.x

Martinussen R, Hayden J, Hogg-Johnson S, Tannock R. (2005) A meta-analysis of working memory impairments in children with attention-deficit/hyperactivity disorder. Journal American Academic Child Adolescent Psychiatry, 44, 377-84. https://doi.org/10.1097/01.chi.0000153228.72591.73

Mello, C. B., Argolo, N., Shayer, B. P. M, Abreu, N., Godinho K. et al. (2011). Versão Abreviada do WISC-III: Correlação entre QI Estimado e QI Total em Crianças Brasileiras. Psicologia: Teoria e Pesquisa, 27(2).

Meyer, M. L, Salimpoor, V.N., Wu, S.S., Geary, D. C., Menon, V. (2010).Differential contribution of specific working memory components to mathematics achievement in 2nd and 3rd graders. Learn Individual Difference, 20: 101-109. https://doi.org/10.1016/j.lindif.2009.08.004

Mukunda, K.V., Hall V.C. (1992) Does performance on memory for order correlate with performance on standardized measures of ability? A meta analysis. Intelligence 16: 81-97. https://doi.org/10.1016/0160-2896(92)90026-N

Nigg, J. (2006) What Causes ADHD? Understanding What Goes Wrong and Why. New York: Guilford Press.

Rasmussen, C. \& Bisanz, J. (2005).Representation and working memory in early arithmetic. Journal of experimental child psychology, 91(2), 137-57. https://doi.org/10.1016/j.jecp.2005.01.004

Rohde, T. E. \& Thompson, L. A. (2007). Predicting academic achievement with cognitive ability. Intelligence, 35(1), 83-92. https://doi.org/10.1016/j.intell.2006.05.004

Stein, L. M. (1994). Teste de Desempenho Escolar: manual para a aplicação e interpretação. São Paulo, Casa do Psicólogo.

Swanson, H. L. (1999). What develops in working memory? A life span perspective. Developmental Psychology, 35(4), 986-1000. https://doi.org/10.1037/0012-1649.35.4.986

Swanson, H. L. (2001). Are working memory deficits in readers with learning disabilities had to change? Journal of Learning Disabilities, 33, 551-566. https://doi.org/10.1177/002221940003300604

Swanson, H. L. \& Beebe-Frankenberger, M. (2004). The relationship between working memory and mathematical problem solving in children at risk and not at risk for math disabilities. Journal of Education Psychology, 96, 471-491. https://doi.org/10.1037/0022-0663.96.3.471

Swanson, H. L. \& Jerman, O. (2006). Math disabilities: A selective meta-analysis of the literature. Review of Educational Research, 76, 249-274. https://doi.org/10.3102/00346543076002249

Swanson, H. L. \& Siegel, L. (2001). Learning disabilities as a working memory deficit. Issues in Education: Contributions from Educational Psychology, 7, 1-48.

Swanson, H. L., Jerman, O., \& Zheng, X. (2008).Growth in working memory and mathematical problem solving in children at risk and not at risk for serious math difficulties. Journal of Educational Psychology, 100, 343-379. https:// doi.org/10.1037/0022-0663.100.2.343

Swanson, H. L. (2006). Working memory and reading disabilities: Both phonological and executive processing deficits are important. In T. P. Alloway \& S. E. Gathercole (Eds.), Working memory in neurodevelopmental conditions (pp. 59-88). East Sussex, UK: Psychology Press. 
Unsworth, N. \& Engle, R. W. (2007). On the division of short-term and working memory: An examination of simple and complex spans and their relation to higher-order abilities. Psychological Bulletin, 133, 1038-1066. https://doi. org/10.1037/0033-2909.133.6.1038

Wechsler, D. (2002). Wisc-III. Escala de Inteligência para Crianças. (V. L. Figueiredo, Trad.). São Paulo: Casa do Psicólogo. (Original publicado em 1949).

Zheng, X., Swanson, H. L., \& Marcoulides, G. A. (2011). Working memory components as predictors of children's mathematical word problem solving. Journal of experimental child psychology, 110(4), 481-98. Elsevier Inc. https:// doi.org/10.1016/j.jecp.2011.06.001

Dados dos autores:

Gustavo Marcelino Siquara - Mestre, Escola Bahiana de Medicina e Saúde Pública.

Cassio dos Santos Lima - Mestrando, Universidade Federal da Bahia.

Neander Abreu - Doutorado, Universidade Federal da Bahia.

Endereço para correspondência:

Gustavo Siquara

Av. Adhemar de Barros, s/n, Pavihão 04, ISP - Ondina

41170-110 Salvador, BA, Brasil

<gustavosiquara@hotmail.com>

Recebido em: 10.07.2017

Aceito em: 09.04.2018 